\title{
Ahlak Rasyonel Bir Sorușturmanın Konusu Olabilir mi? Aliya İzetbegoviç'te Akıl ve Ahlak
}

\author{
Could Morality be the Subject of a Rational Investigation? Alija Izetbe- \\ govic's Mind and Morality

\section{ZÜBEYİR OVACIK (0)} \\ Aksaray University

Abstract: This study discusses, from the example of Alija Izetbegović, what the legitimate instruments are that will enable us to talk about morality. Considering that a philosophical investigation will gain legitimacy by reason, one of the main areas of discussion of philosophy, the moral domain, needs to be discussed rationally. But can we use a method which we use in analyzing an objective structure which is current in nature, in the moral field which is the field of what should be? Modern philosophy has a methodological mistake that results in inconsistency in the discussion of the practical field of philosophy, like moral. In this context, Alija emphasizes the special fields of human experiences, such as art, religion and morality out of science.

Keywords: Alija Izetbegović, ethics, morals, rational morality, reason and morality.

(C) Ovacık, Z. (2019). Ahlak Rasyonel Bir Sorușturmanın Konusu Olabilir mi? Aliya İzetbegoviç'te Akıl ve Ahlak. Beytulhikme An International fournal of Philosophy, 9 (I), 2 II-229. 


\section{Giriș}

Varlığın kökenine, ereğine ve insan varolușunun anlam ve amacına dair tutarlığı esas alan kapsamlı bir sorușturma türü olarak felsefi düșünce, özgün bir zihinsel tutuma karșllık gelmektedir. Böylesine özgün bir düşüncenin mimarları olan filozoflar, felsefenin teorik ve pratik alanlarına tekabül eden pek çok problemi tartışma konusu yapmıșlardır. Filozoflar, ontolojik ve epistemolojik çabalarıyla da irtibatlı bir șekilde zihinsel mesailerinin büyük bir kısmını ahlak üzerine yoğunlaștırmıșlardır. Öyle ki, hiçbir insanın bilerek kötülük yapmayacağını ileri süren Sokrates, erdem merkezli bir felsefi sistem inșa ederken, Platon ve Aristoteles'in de felsefi serüvenlerine bakıldığında onların da ahlaki yetkinliğin bireysel ve toplumsal planda nasıl ortaya çıkacağına dair problematiği merkeze aldıklarını görmek mümkündür. Modern felsefenin kurucu ismi Descartes da bütün bir felsefeyi bir ağaç metaforuyla açıklamaktadır ki, ona göre bu ağacın köklerini metafizik, gövdesini fizik oluștururken, gövdeden çıkan dalların da hekimlik, teknik ve ahlak șeklinde üç ana dalda toplanabilecek diğer bilimlerden ibaret olduğunu belirtmektedir. Böylelikle nihai noktada ahlaka yer vermekte olan Descartes, burada ahlakla kastettiği șeyin, diğer ilimlerin tam bir bilgisini gerektiren ve bilgeliğin en son basamağını teșkil eden en yüksek ve en tam ahlak olduğunu özellikle vurgulamaktadır. Zira Descartes'a göre nasıl ki meyveler ağaçların köklerinden veya gövdesinden değil de dallarının ucundan toplanıyorsa, aynı șekilde felsefenin de asıl faydası en son öğrenilebilen bölümlerinden yani ahlaktan elde edilir (Descartes, I997:I7).

Felsefi düșüncenin kendisine yöneldiği temel bir alan olarak ahlaka dair bir tartıșmaya nereden bașlamak gerekir? Evleviyetle takdir edilir ki, felsefi antropoloji çalışmaları, felsefi etik için çok büyük önem arz etmektedir. Zira felsefi etik ve felsefi antropoloji çok yönlü bağımlılık ilișkisi içerisindedirler (Delius, 200ı: 355, Heinemann, 200ı: 368). Bütün etik teorilerin bir insan doğası anlayıșına yaslandıklarını dikkate aldı̆̆ımızda Aliya İzzetbegoviç'te etiğe dair bir sorușturma, her șeyden önce onun insanın doğasına dair çözümlemelerini ortaya koymayı gerekli kılacaktır. Aliya'nın insan doğasını nasıl ele aldığını çözümleyen bir çalıșmayı Aliya İzetbegoviç'te Felsefi Antropoloji (Ovacık, 2015: I86-2I7) bașlı̆̆ı altında daha önce gerçekleștirmiș bulunmaktayız. Hâlihazırdaki bu çalıșma, Aliya İz- 
zetbegoviç örneğinden hareketle ahlak üzerine konuşmayı mümkün kılacak meșru enstrümanların neler olduğunu tartışmaktadır. Ahlaka dair bir sorușturmada, felsefi antropolojik bakıș açısının dikkate alınmasıyla tutar11 bir metodolojik tutum geliștirilebileceği göz önüne alındığında, öncelikle insanın neliği ve insanın ahlaki olanla nasıl bir ilișki içerisinde olduğu meselesini ortaya koymak gerekmektedir.

\section{Ahlak Varlığı Olarak İnsan}

Etik sorgulamalar açısından önemli addedilen felsefi antropolojik çalışmaların bazılarından çıkan sonuçlardan hareketle, insanı "akıllı bir varlık" (animale rationale) olarak tanımlayan geleneksel bakıș açısı yeterli bulunmamaktadır. Dolayısıyla Aliya'nın da paylaştı̆̆ı bu bakıș açısına göre, insanın, aklının dıșında sahip olduğu bașka özellik ve niteliklerle ön plana çıkartılması gerekmektedir. Zira rasyonel niteliğinin dıșında insanın bașka niteliklere sahip olușu, onun ahlaksal eylemlerine yeni yorumlar getirme imkânı sunmaktadır. Nitekim çağdaș felsefenin öne çıkan akımlarından biri olarak varoluşçuluğun, insanın bunalımına, kaygısına vurgu yapmakta olușunu, örneğin Heidegger'in insanın kaygı niteliğini ön plana çıkartmakta oluşunu bu çerçevede değerlendirmek mümkündür (Delius, 200I: 355). Pek çok varoluşçu filozofla aynı çağda yaşayan ve özellikle Doğu Batı Arasında İslam adlı eserinde 'absurd felsefeler'in temel yönelimlerine yer veren, böylelikle onların felsefelerini yakından gözlemleme imkânına sahip olduğu anlașılan Aliya'ya göre, insan ruhunun varlığına inanmak, insanın kaygı, șüphe, isyan potansiyeline, insanın ıslah edilemez bir fert olduğuna, dolayısıyla yeknesak bir varlık olmadığına, refah ve konforu temin edilse bile insanın bir gün bunları reddedip hürriyetini, insanlik onurunu geri isteyeceğine inanmak demektir (Aliya, 2008: 25I). Aliya, insana dair sorușturmalarında onun ahlaki kaygılara sahip bir varlık olușunu ön plana çıkartmaktadır.

İnsanın bir ahlak varlığı olduğunu vurgulayan Aliya'ya göre, insan ile hayvan arasında biyolojik fonksiyonlar açısından, bir bedene sahip olmaları açısından aralarında bir benzerlik söz konusu iken; özle ilgili olarak bir bașka ifadeyle manevi açıdan tam bir zıtlık gündeme gelecektir. Bu zıtl1ğın ahlakın ve hukukun kapsama alanına dâhil olmak veya olmamak șeklinde bir sonucu ürettiğine dikkat etmek gerekmektedir (Aliya, 20o8: 73). 
Böylelikle insan ile hayvan arasındaki temel farkın zekâ ve fizikten kaynaklanmadığını, bunun yerine din, ahlak ve estetik gibi durumların hesaba katılması gerektiğinin altını özenle çizen (Aliya, 2008: 46) Aliya'ya göre hayvan için tabii düzen içerisinde bir hayat söz konusu iken, insan için ise hakiki dünyanın dıșında, bundan daha önemli olan hayali bir dünya söz konusudur. Nitekim ilkel insanların avcılık faaliyetinde hayvanla aralarındaki farkın manevi bir fark olduğuna dikkat çekmek durumundayız. Zira insan avında başarılı olabilmek için dua eder birtakım törensel süreçlerden geçerdi (Aliya, 2008: 42-43). Atkinson'un İlk Kanun adlı eserinde çeșitli iptidai yasakların ilk vahșiler arasında bile mevcut olduğunu belirttiğini kaydeden (Aliya, 20o8: 46) Aliya'ya göre "din, büyü, oyunlar, kurban sunmak, tabular, ahlaki yasaklar" gibi tarih öncesi toplumların yanı sıra medeni toplumlarda da mevcut bulunan unsurlar, sadece insani varlık alanına ait olan hususiyetlerdir. Bu çerçevede tabu teriminin erken insanlık döneminde ahlaki mahiyetli bir yasak anlamında kullanıldı̆̆ına dikkati çeken (Aliya, 2008: 47) Aliya, hayvanın hayatta kalmak için avlandı̆̆ında, mantıki rasyonel hareket edip, kendisine hiçbir sınırlama koymadığını, insan gibi hayvanı sınırlayan garip tabuların ve inanç ilkelerinin bulunmadığını özellikle vurgulamaktadır (Aliya, 2008: 4I). Nihayetinde insanın arzularını sınırlandırması, hayatın zevklerine sırt çevirmesi, bașkaları için fedakârlık yapma tutumu, hayvanda olmayıp insanda olan ahlaki özelliklerdir (Aliya, 2008: 39). İnsan varlı̆̆ı söz konusu olduğunda nefs (psyche) ve ruh (soul) arasında bir ayrıma gitmekte olan Aliya'ya göre bunlar arasındaki ayrım, terminolojik bir farklılık olmayıp, mahiyete ilișkin bir farklılıktır. Bu çerçevede nefs, bilimsel bir kategori olup hakkında sağlık, hastalık formları kullanılabilirken, tezkiye ve günah gibi standartlar ise ruhun standartları olup nefse uygun düșmemektedir (Aliya, 2015: 214).

Aliya'ya göre, insan ya iyidir ya da kötüdür ama hayvan veya melek gibi masum değildir. Dolayısıyla o, günah yüklü olmasa da masum da değildir. İnsan bir anlamda kendisine verilmiș özgürlüğü kullanmaya mahkumdur. İyi veya kötü olmaya tek kelimeyle insan olmaya mecburdur (Aliya, 2008: 76). Aliya'ya göre, insan, ister ahlaki yasalara uygun davransın isterse davranmasın, ahlaki alanın dıșına çıkamamaktadır. Nihayetinde insan için iyi ile kötünün ötesinde bir alan söz konusu değildir. Aliya, bu durumu “o, kendi kendini dıșarı atamaz.” șeklinde ifade etmektedir (Ali- 
ya, 2008: 75). Nitekim erdemli insanların sayısının az olduğunu, fakat son derece küçük bir azınlığı teșkil eden bu ahlak kahramanlarının insanlığın ve her insanın gurur kaynağı olduğunun altını çizen Aliya’ya göre ahlak, insanlık için vazgeçilmezdir. Zira insan ya hakikaten ya da sahte olarak her zaman ahlaklıdır. Dolayısıyla o ahlaktan vazgeçemez. Bu anlamda adalet, hakikat, eșitlik, özgürlük gibi ahlaki kavramlar, ister samimi bir șekilde olsun, isterse riyâkarlıkla, menfaatle, sahte olarak gündeme gelsin, nihayetinde hep gündemde olmuștur. Böylelikle Aliya'ya göre sahte ahlak bile hakiki ahlakın kıymetinden bahseder. Bu durum tıpkı sahte paranın geçici de olsa hakiki paradan değer kazanması gibidir (Aliya, 2008: I72I73). Böylelikle Aliya'ya göre insanın ahlaki bir varlık olușu göz önüne alındı̆̆ında, evrimci antropolojinin temele aldığı acımasız hayat rekabeti varsayımının boșa çıkacağı görülecektir. Zira hem iptidai hem de medeni toplumlarda cârî olabilen bir rekabet ortamı göz önüne alındığında insanın ahlaki bir hayatı tercih etmesi durumunda varolușunun bekası tehdit altında olacaktır. Bundan dolayıdır ki, hayvanlarla kıyaslandığında insan, ahlakla mukayyet olmasının getirdiği sınırlamaları üstün zekâsıyla telafi ederek varlığını koruyabilmiștir. İnsandaki zekâ ahlaki bir sınırlamaya tabi olmayan hayvanlarda olsaydı hayvanlar en kisa zamanda yok olurlardı (Aliya, 2008: 39).

İnsanın ahlaki kaygılarla insan olduğunun altını çizen Aliya’ya göre insanı eșyayla bir tutan her șey gayri insanidir. Böylesi bir bakıș açısı insanı özgür varsaymamaktadır. Oysa insanı ahlaken sorumlu tutmak ve onu cezalandırmak insanidir. Zira Aliya'ya göre son derece insani olan cezalar olduğu gibi, hiç de insani olmayan bağıșlamalar vardır. Engizisyoncular insanın ruhunu kurtarmak için bedenini yaktıklarını iddia ediyorlardı. Modern engizitörler ise bedeni için ruhu "yakmaktadırlar", ruhu bedene feda etmektedirler. Bu da asla insani değildir. Zira insanı üretim ve tüketim fonksiyonuna indirgemek asla hümanizma olamaz, olsa olsa dehumanizasyon olur. Bu çerçevede insanı düșünce üretmekten, seçme durumundan uzaklaștıracak bir eğitim, yani endoktrinasyon da asla hümanizma değildir. Bilakis bu, insanı metalaștırmaktır. Çünkü insanı insan yapan muafiyetler değildir, mükellefiyetlerdir (Aliya, 2008: 8I, 82). Aliya'ya göre insan, "kâlû belâ'dan" "dünyanın içine" itildiğinden beri bu böyledir. Evet, dıșarıdaki hayatın dıșında bir hayatın mevcudiyetine ilișkin açık akli delil- 
ler olmasa bile insan hayatının sadece üretmekten ve tüketmekten ibaret olmadığını çok temel bir hissiyat olarak tașımaktayız. Nitekim bir filozof veya düșünür daha yüce olan bașka bir hayatın mevcudiyetine düșünerek ulașmasa bile hayatın maddi yönlerini ihmal pahasına böylesi bir araștırmanın bizzat kendisi bile beșeri hayatın daha yüce șekline bir ișaret olsa gerek. Ahlak ve hürriyet adına, bașkaları için yapılan her mücadele insan hayatının ebedi yönüne, bașka bir boyutuna işaret eder (Aliya, 2008: 13). İnsanın alamet-i farikası olarak geriye ahlakın, bir bașka ifadeyle özgür ve bilinçli bir iradeyle iyinin lehinde ve kötünün aleyhinde tercih yapma özelliğinin kaldığını görürüz. Hayvanlar ahlaki varlıklar olamazlar, zira onlar seçim yapmaz ve hür değildirler. Ahlak ve ahlaksızlık sadece insan öznesine yüklem yapacağımız niteliklerdir (Aliya, 2015: I76).

Aliya, insanın en belirgin özelliğinin seçme kabiliyeti olduğuna vurgu yapmaktadır (Aliya, 20I5: 2OI). O, insana dair tartıșmaların özgürlük, sorumluluk, ödev, hak gibi kavramlar eșliğinde etik ekseninde yürütülen öze ait tartıșmalar olușuna özellikle dikkatleri çekmektedir. Söz konusu kavramların ontolojiden, epistemolojiye ve siyaset felsefesine uzanan boyutları hesaba katıldığında geniș bir felsefi evrende tartıșılması gündeme gelecektir.

\section{Bilim ve Ahlak (Bilim, Din, Sanat ve Ahlak)}

Doğu ve Batı Arasında İslam adlı eseri bașta olmak üzere pek çok eserinde ahlak, din, sanat, kültür ve uygarlık gibi beșeri tecrübe alanlarını bütün bir düșünce tarihinden de örnekler vererek felsefi nitelikte bir sorgulamanın konusu yapan Aliya İzzetbegoviç, insanı ahlaki bir varlık olarak konumlandırmakta ve ahlaka dair felsefi bir sorușturmanın imkânlarını araștırmaktadır. Modern dönemle birlikte bilimin ölçütlerini felsefeye tașıma tutumu yaygınlık kazandığına göre ahlaka ilișkin felsefi tartıșmaları bilimsel bir çerçeve içerisinde gerçekleștirmek mümkün müdür? Bilindiği üzere erdemle bilgiyi özdeșleștiren Sokrates, bütün felsefi sorușturmalarını ahlakın epistemolojik zeminine ilișkin bir imkânı göz önünde bulundurarak sürdürür. Modern dönemde düșüncenin temel yönelimini belirleyen bilimsellik paradigması, ahlakın bilimsel bir çerçevesinin imkânı meselesini, felsefi düșüncenin temel tartıșma alanlarından birisi haline getirmiștir. Pek çok modern dönem filozofunun gündemini ișgal 
eden bu tartıșmanın Kant'ta daha net bir izleğini görmek mümkündür. (Akarsu, I999: I2 vd.).

Bilimin alanıyla ahlakın evreni arasında temel bir ayrımın olduğunu özellikle vurgulayan Aliya, ahlaka ilișkin temellendirmelerinde tutarlı bir yöntem arayıșının izlerini sürmektedir. Aliya, bilimin sebep sonuç ilișkisi içerisinde gözlem ve deneye dayanan bir yapıyla kendini sınırlandırdığını, dolayısıyla sadece tabiatın mekanizmasına hapsolduğunu, fakat bilim adamının insan olması hasebiyle bu sinırlarda durmayıp daha ötesine, insani alana geçtiğine dikkat çekmektedir. Nitekim, Aliya'ya göre Oppenheimer'ın atom bombasını icat ederken Hint felsefesine ihtiyaç duymayıp; fakat bombanın ortaya çıkardığı tahribattan sonra Hint felsefesiyle yoğun bir șekilde meșgul olması, yine Einstein'ın Dostoyevski ile özellikle onun "Karamazov Kardeșler" adlı eseriyle ilgilenmesi, insani olana doğru meyle ișaret etmektedir (Aliya, 2008: I87). Ona göre insani diyebileceğimiz meseleler, örneğin insan onuruna ilișkin bir tartıșmayı modern bilim çerçevesinde konușulamaz. Çünkü modern bilim, nesnel bir gözlem yoluyla insanların eșitliğini değil, olsa olsa eșitsizliğini ispat edebilir. Dolayısıyla "bilimsel bir ırkçllık" gayet mümkün ve mantıki görünmektedir (Aliya, 2008: 78). Aliya, Fransız ihtilalinin “eșitlik-hürriyet-kardeșlik” șeklindeki meșhur üçlemesinin bilimden türemediğini ve bunların bilimsel ispatının yapılamayacağını belirtmektedir (Aliya, 2008: ı82). Aynı șekilde "ilerleme" düșüncesi de ona göre ahlak fenomeniyle çatıșmaktadır. (Aliya, 2008: I78).

Aliya'ya göre bilim ile ahlak arasındaki gerilimi pratik hayatta somut bir șekilde gözlemleme imkânına sahibiz. Bu çerçevede örneğin bilim, suni tohumlama, tüp bebek, ötenazi gibi uygulamaları ortaya koyarken; ahlaki sistemler insanın nesneye indirgenmesi, dolayısıyla manipülasyon ve suiistimallere yol açması sebebiyle bunlara karşı çıkmaktadır. Aliya, bilimin suni tohumlama, ötenazi gibi uygulamalarının teknik açıdan gayet akli ve mantıki olduğunu, dolayısıyla bunlara karșı çıkarken herhangi bir bilimsel akli argüman kullanmayacağımızı özellikle vurgular. Bilimin suiistimallerine ancak bilim dıșı bir alanla karșı koyabiliriz. $\mathrm{O}$ da ahlaki alandır (Aliya, 2008: 184-I85).

$\mathrm{Bu}$ arada bilim ile ahlakın kesiștiği alanların da olabileceğine dikkat çeken Aliya bu konuda yakın akraba evliği konusunda bilimin verilerinin ahlaki alana katkı sunduğuna dair örnek verir. Bu konuda bilim ile ahlakın 
tam bir mutabakat içerisinde olduğuna belirten Aliya, Rus biyolog Timiryazev'in "Bitkilerin Hayatı" kitabından alıntı yapmaktadır: "Yakın akraba evliliğinin çocukların sağlığına kötü tesir ettiğini ispat eden birçok șey vardır. Böyle delillere bugün ihtiyacımız yoktur. Çünkü deney bunun genel bir kanun olduğunu ve yalnız insanlar ile hayvanlar dünyasında değil; bitki dünyasında da geçerli olduğunu göstermektedir. Ve hatta bu bütün organik dünyada cari bir kanundur. Bu bitkilerde olduğu kadar bașka hiçbir yerde o kadar așikâr değildir" Timiryazev'in "Bitkilerin Hayatı" s. I34. (Aliya, 2008: 310-3II).

Yukarıdaki örnekte görüldügü üzere bilim bazı durumlarda ahlaki argümanlara katkı sunuyor olsa da ahlakın referans çerçevesi olamayacaktır. $\mathrm{Bu}$ çerçevede ahlaka dair bir sorușturmanın bilimin dayandığı nedensellik çerçevesinde ele alınamayacağına özellikle vurgu yapmakta olan Aliya, modern bilimin esasında maddenin niceliksel bir açıklaması olușuna dikkatleri çekerek bu alanda nitelik ve değerin hesaba katılmadığını belirtmektedir (Aliya, 2008: 130). Bundan dolayıdır ki, Aliya, esas araștırma konuları olmalarına rağmen hayatın ve ruhun mahiyetine ilișkin biyoloji ve psikolojinin tatmin edici șeyler söylemekten uzak olmalarının șașırtıcı olmadığını belirtir (Aliya, 2008: 57). Zira Aliya'ya göre tabiatta mutlak mekanik bir hareket söz konusu iken; hayat fenomeninde böylesi açık bir sebeplilikten söz edemeyiz. Sanki organizma aynı anda kendinin hem sebebi hem de neticesidir (Aliya, 2015: 242).

Aliya'ya göre tabiatın determinizmine karșılık; insanın kaderi vardır (Aliya, 2008: 379). Bu açıdan bilim, maddi dünyaya ilișkin bir etkinlikle ilișkilidir; insanın varolușu ise maddi dünyanın ötesinde bir dünyayı varsaymayı gerekli kılmaktadır. Bu çerçevede Aliya'ya göre insan söz konusu olduğunda, bilimden daha çok din, sanat ve ahlak gibi beșeri tecrübe alanları gündeme gelecektir. Bu doğrultuda Aliya'nın ahlakı bilimle yan yana getirmekten ziyade, ahlakı sanat ve dinle aynı kategoride değerlendirdiğini söyleyebiliriz. Zira sanat, din ve ahlak yaratılıșla ortaya çıkan aynı ağacın dallarıdırlar (Aliya, 2008: 129). Böylelikle sanat, ahlak ve dinin insanın beșerîlikten insaniliğe doğru gelișmesinde ortaya çıkan tecrübeler olduğuna dikkat çeken Aliya'ya göre sanat, ahlak ve dinin özlerine doğru bir soyutlama yapmamız durumunda orada bulacağımızın arzu, niyet ve hürriyet olacağına dikkat çekmektedir. Kısacası bu öz, saf insaniyet olacaktır 
(Aliya, 2008: I62). Bu çerçevede sanat, felsefe ve dinin asıl manası da insanın dikkatini muammalara, sırlara ve sorulara çekmelerinde ortaya çıkmaktadır. Bu ise bilmediğimize ilișkin bir bilincin uyanması demektir (Aliya, 2008: 70). Nihayetinde din, dolaysıyla sanat ve ahlak, insanın kaybettiği bir dünyayı arayıșıyla açıklanmaktadır (Aliya, 2008: 5I). Bu anlamda örneğin sanat, insanın yalnızlığına, entelektüel ve ahlaki kapasitesinin yoksunluğuna dikkatleri yöneltmektedir (Aliya, 2008: I23). Uzay ve zaman Aliya'ya göre din ve ahlak tıpkı sanat gibi zaman dıșıdır, zamandan bağımsızdırlar. Burada bilimin ilerlemesi gibi bir durumdan söz edemeyiz (Aliya, 2008: 220, 222, 223).

Modern felsefenin Descartes'dan bu yana matematik fizik yöntemini felsefenin yegâne yöntemi kılma arayıșlarının (Türer, 20I7: 3I4 vd.) mantıkçı pozitivizmde daha ileri bir seviye kazandığını göz önünde bulunduran Aliya, rasyonaliteyle ilișkisi açısından modern felsefenin pozisyonunu sanattan uzak; fakat bilimle yan yana olan bir konumla açıklamaktadır. Aliya, modern bilim ile felsefenin konuları itibarıla farklı olsalar da metot bakımından aynı olduklarını belirtmekte ve bu meyanda i8. yüzyıl rasyonalist filozoflarının geometrik yöntemlerini hatırlatmaktadır. $\mathrm{Bu}$ çerçevede Spinoza'nın Ethica'sını geometrik yöntemle ortaya koyuşunu örnek veren Aliya, yine Malebranch, Christian Wolf gibi rasyonalist dedüksiyon yöntemini benimseyenleri hatırlatmaktadır. Bu noktada itirazlarını yükselten Aliya, felsefenin insan ve ahlaka dair meseleleri de tabiat zemininden ele aldığını, dolayısıyla rasyonel, matematiksel yöntemleri kullandığını ve bu yüzden hayata dair kușatıcı açıklamalar yapamadığına, hayat hakkında çoğunlukla bilgisiz kaldığına işaret etmektedir (Aliya, 2008: 132). Esasında Aliya'nın burada dikkat çektiği bu tavır özellikle mantıkçı pozitivistlerin tavrı olsa gerektir.

\section{3. İrrasyonel Bir Kategori Olarak Ahlak}

Etik insan varolușunun özü ve anlamı açısından doğrudan değerler alanı ile ilișkili bir disiplindir. Bu bakımdan etik araștırmalarda farklı yöntemlere ihtiyaç vardır. İnsan varoluşunun özüne doğrudan temas eden değerler alanını konu edinen etiğe dair çalıșmalara bakıldığında etik kuramlar, genellikle normatif kuramlar ve çözümleyici kuramlar şeklinde ikiye ayrılmaktadır. Bu yöntemlerden hangisinin kullanılacağı araștırma- 
nın amaçlarına göre farklılık gösterebilir. Etik araștırmalarının bilimsel bir tartışmanın konusu olamayacaklarına dikkat çeken yaklaşımlar açısından bakıldığında, etik araștırmaların yöntemleriyle matematiksel/doğa bilimsel araștırmaların yöntemleri arasında benzerlikler kurmak doğru bir metodolojik tutum olmayacaktır. Zira etik araștırmalarında matematiksel/doğa bilimsel yöntemlere bașvurmak etik normların temellerine nüfuz edilememe durumunu ortaya çıkaracaktır. Daha geniş bir çerçeveden problemi ifade etmek gerekirse, olgu ve değer ayrımından yola çıkıldığında (Ovacık, Evren, 20I5: 248) her iki araștırma alanlarının farklı yöntemlerle ele alınması gerekmektedir. Böylesi bir ayrım yapılmayıp olgu ve değerin özdeș kılınması durumunda, olan ile olması gereken arasındaki mesafe ortadan kalkmıș olacağından ahlaki idealizmin imkânı ortadan kalkmış olacaktır. Nihayetinde etik olgular özgül olgular olduklarından bunların örneğin içe bakıș ve sezgi gibi kendine has yöntemleri olmalıdır (Delius, 2001: 355, 356; Cevizci, 2005: 935,936).

Ahlakın sorușturulmasında bilimsel yöntemin dıșında farklı yöntem arayışlarına dikkat çeken Aliya'ya göre akıl, tabiata yönelirken salt tabiatı, yani tabiattaki sebeplilik örgüsünü keșfetmektedir. Tabiata yönelișinde böylesine bir nedensellik çerçevesi içerisinde iș görmeyi alıșkanlık haline getiren akıl; insan eylemlerine dair çıkarımlarında da yine tabiata baktığı șekilde bakarak içgüdülerin iki temel amirini, acı ve zevkin hâkimiyetini keșfedecektir. Bilinçliliğin ve özgür seçimin ahlaki eylemin belirlenmesinde vazgeçilmez iki unsur oluşunun altını özenle çizen Aliya, tam bu noktada acı ve zevk șeklindeki güdülerin ancak insanın köleliğini, hür olmay1șını açıklayabileceğine dikkat çekmektedir. Aliya, söz konusu yanlıș düşünme mekanizmasının nedensellik çerçevesinden hareket etmesinden dolayı Tanri'yı sadece ilk sebep ("hareketsiz muharrik"), ruhu "psik", sanatı ise eser ve teknikten ibaret olarak gördügüne ișaret etmektedir. Aliya bu çerçevede Hume'un şu ifadelerine yer vermektedir: "Bir suç, akıl için, muayyen bir șahsiyet ve o durumla ilgili bir sürü motif, düșünce ve fiillerden bașka bir șey değildir. Bu bağı biz tetkik edip, fiilin olușması ve tahakkuk ettirilmesini izah edebiliriz. Fakat fiili ahlak bakımından bir kötülük olarak vasıflandıran o kötüleme tavrıysa, söz hakkını ancak hissiyatımıza tanırsak meydana gelir.” Aliya, Hume'dan șu ifadeleri de aktarmaya devam etmektedir: "akıl tümüyle șeyler arasındaki münasebetleri keșfet- 
mekten bașka bir șey yapmağa muktedir değildir; değer yargısına, bilakis, yepyeni bir unsur iltihak ettiğinde fiiliyatta mevcut olmayan bu unsur ancak hissiyatın üretim gücü ile açıklanabilir.” (Aliya, 2008: I82, I84). Hume gibi ahlaki o/alanın açıklanmasında akıl yerine duygu motifini belirleyici kılan bir isme doğrudan atıfta bulunan Aliya, nihayetinde ahlak alanında cereyan eden bir tartışmanın mantıksal veya matematiksel bir tartıșma olmadığını ısrarla vurgulamaktadır. Nitekim ahlaki olan eylemler ile ahlaki olmayan eylemlerin tefrik edilmesinde özel bir eğitim ve zekânın șart olmaması da ahlaki yargıların akli istidlalle ulașılan yargılar olmadığını bize göstermektedir (Aliya, 2008: I82, I84).

Aliya, bir ahlak sisteminin ancak metafizik bir zemin üzerinden yükselebileceğini düșünmekte ve ahlaki bir eylemin bilinçlilik ve özgür bir tercih șeklinde iki temel unsura ihtiyaç duymakta olduğunu düșünmektedir. Halbuki, Aliya'ya göre modern bilim paradigması olgular dünyasına yönelirken kendisine yaslandığı maddecilik anlayıșı gereği, determinist bir çözümlemeyi esas almaktadır. Böylesine bir çözümleme ise, "olması gereken șeylerin âlemi” olarak ahlakın temelini teșkil eden özgürlüğü ortadan kaldırmaktadır. Nitekim Aliya'ya göre Fransız materyalist Diderot, insanın iyi ve kötü șeklinde nitelendirilebilecek eylemlerinin özgürce ortaya çıkan eylemler olmadığını, zira insan eylemleri alanında da maddi düzlemde ortaya çıkan belirlenimciliğin geçerli olduğunu düșünmekle ve böylelikle de insan için ahlaki bir evrenin imkânına geçit vermemekle esasında materyalist sistem içerisinde çok tutarlı bir şekilde hareket etmiştir (Aliya, 2015: 218, 245). Zira Aliya'ya göre insan düşüncesinin ahlaka ilişkin ortaya koyduğu birikime eğildiğimizde ahlak düşüncesinin geçirdiği bütün dönüșüm ve değișimlerde hürriyet fikrinin sabit bir değer olarak kaldığını görürüz. Böylelikle hürriyetin reddedilmesiyle ahlakın da imkânı ortadan kalkacaktır. Aliya, bu çerçevede Hegel'den aktararak maddenin özünün ağırlık olması gibi; ruhunun özünün de hürriyet olduğunu belirtmektedir. Bir başka ifadeyle fizik için mekân veya miktar ne ise, ahlak için de hürriyetin o olduğunu belirtmektedir (Aliya, 2008: 18I). Bu noktada Aliya, aklın mekân ve miktarı idrak ettiğini; fakat hürriyeti idrak edemediğinin altını çizmektedir. Zira Aliya'ya göre hürriyet, akıl dıșı bir kategoridir. Dolayısıyla, hakiki ahlak ile akıl arasındaki ayrılık da burada ortaya çıkmaktadır. 
Aliya'ya, göre aklın fonksiyonu, her șeyde tabiatı, mekanizmayı, hesabı keșfetmek üzerine kuruludur. Böylesi bir keșif sonunda akıl, her șeyin içinde kendini görecektir/keșfedecektir. Dolayısıyla akıl, sürekli bir daire içinde dönmektedir. Böylelikle akıl, tabiat içerisinde kendi mekanizmasından daha büyük bir șeyle karșılașmamaktadır. Aliya'ya göre pek çok ahlak teorilerinin paradoksu da iște aklın bu yapısından kaynaklanmaktadır. Söz konusu teorilerin fedakârlık = hodbinlik, zevkin inkârı = zevk șeklinde paradoksal sonuçlara vardıklarını belirten Aliya, böylesi paradoksların Voltaire'ın saçmaya indirgeme (Reductio ad absurdum) metodunu ortaya koymasına yol açtığını hatırlatır. Nihayetinde Aliya'ya göre ahlakın akli, mantıki tahlili, bu tahlili yapanın kendisini bile hayret içinde bırakacak șekilde ahlakı tabiata, menfaatperestliğe, bencilliğe irca edecektir (Aliya, 2008: I8I).

Hâlbuki hakiki ahlakın șahsi menfaatten bağımsız hareket etmek olduğuna ișaret eden Aliya, bu çerçevede Aristoteles'in Nikomakbos'a Etik'inde böylesine bir paradoksu yansıttı̆̆ını belirtmektedir. Aristoteles, diğerkâmlığı hodbinliğe dayandırmaktadır: "Biz kahramanca davranmada da hodbinlik sahası dıșına çıkmıyoruz, zira bașkaları uğruna ölenler bile büyük ve güzel olanı sadece kendileri için seçerler” Aliya'ya göre Aristoteles, burada hodbinlik kelimesini normal anlamının dıșına tașacak șekilde hatta onun tam tersine hodbinliği inkâr olarak fedakârlık anlamında kullandığını vurgulamaktadır. Örneğin yangın çıkmıs, bir evde çocuk kurtarmak üzere giren kimsenin bu hareketinin bir menfaate dayandığını söyleyebilir miyiz? Aliya, burada iyilik uğruna kendini feda edenin bir menfaate dayandığını fakat bunun ahlaki, mutlak anlamda bir menfaat olduğunu belirtmektedir. Bu anlamdaki bir menfaatle fedakârlık birbirleriyle çatıșmazlar. Aliya'ya göre alelade menfaat ile tabiri caizse ahlaki menfaat arasında bir ayrım yapabilmemiz için bu dünya ile öbür dünya arasında bir ayrıma gitmemiz gerekmektedir. Buna göre ancak öbür dünyanın mevcudiyetine bağlı olarak bir menfaatten söz edebiliriz. Zira bu dünyadaki sıradan anlamıyla menfaat ile öbür dünyadaki menfaat arasında ise așılmas1 mümkün olmayan hayat vardır (Aliya, 2008: 200).

Aliya'ya göre akıl, yalnızca șeyler arasındaki ilișkileri inceleyebilir. Ahlaki bir yargı ortaya koymada, bir davranıșın iyi ve kötü olduğunu belirlemede akıl, hakiki anlamda hüküm veremez. Örneğin bütün insanları 
manevi olarak tekdüze biçime sokmanın doğru olmadığı hükmünün ahlaken doğru olmadığını herkes kabul edebilir, fakat bunun bilimsel açıklaması yapılamaz. Dolayısıyla bir șeyin ahlaken "iyi olmayıșı” ilmen ispat edilemez. Aliya bu durumu güzel ile güzel olmayan arasındaki ayrımın bilimsel olarak mümkün olmayıșına benzetir. Aynı șekilde sanat eserinde de hakiki sanat ile sözde sanat arasındaki ayrımda da bilimsel bir müdahaleden söz edemeyiz (Aliya, 2008: I82). Böylelikle Aliya'ya göre tabiatla akıl arasında bir mutabakattan söz edebiliriz. Dolayısıyla akıl, tabiat alanında bir hüküm ortaya koyabilecektir; fakat aynı akıl, haklı haksız, iyi ile kötü arasında bir farkı göremeyecektir. Zira bu keyfiyetler tabiat içerisinde bulunmaz.

Aliya, iyi bir insanın daima mutlu; kötü bir insanın da daima mutsuz olduğu șeklindeki ahlaki yaklașımın aklen anlașılır olmadığını belirtmektedir (Aliya, 2008: I82). Bu çerçevede Aliya, Victor Hugo'nun Sefiller'indeki kahraman Jean Valjean'ın yașadığı iç çatışmalı duruma işaret ederken insan aklı ile ruhu ile daha doğrusu vicdanı arasındaki çatıșmaya dikkat çeker. Özellikle ahlaki bir fenomende ortaya çıkan çatıșma bu iki nitelik arasındaki bir çatıșmadır. Aliya, bu çatıșmanın, tartıșmanın mantıki ve matematiksel bir tartıșma olmadığını, zira iki ayrı keyfiyete ait durumların aynı hesap içerisinde değerlendirilemeyeceğini belirtir. Akıl ve vicdana ilişkin deliller, iki ayrı keyfiyet olduğu için birbirleriyle matematiksel bir ilișki içerisine sokulamaz. Aliya, bunların iki ayrı âleme semaya ve arza ait olduğunu vurgular. Dolayısıyla burada Aliya’ya göre: “...Bu dramatik çıkmazda insanın yalnız kendisi, kendisi için ve kendisi içinde seçme yapabilir..." (Aliya, 20o8: I83). Böylelikle ahlak alanında akıl ile vicdan arasında bir çatıșmayı hatırlatan Aliya'ya göre, ahlaki değerler alanında akli bir analiz yapamayız (Aliya, 2008: I83). Ahlaki fenomenlerin bilimsel ispatının mümkün olmadığın düșünen Aliya: “... akıl, manevi sesimizi haklı bulmuyor veya destekleyemiyor" diye vazifemizi ifa etmekten vaz mı geçeceğiz?" sorusunu sorar. Aliya, vazgeçmememiz için kendimize aklın dıșında sebebini bilmeden, kendine has bir kesinliğe yaslanarak, yani inanarak aklımıza karșı bir tutum almak zorunda kalacağımıza ișaret etmektedir (Aliya, 2008: ı84). Nihayetinde Aliya'ya göre ahlak ne fonksiyonel ne de rasyoneldir. Aliya, bu durumu șu çarpıcı örnekle açıklamaktadır: 
Eğer hayatımı tehlikeye atmak suretiyle komşumun çocuğunu kurtarmak üzere yanan eve girip kucağımda ölmüş çocukla dönsem, neticesiz kalan hareketimin kıymetsiz olduğu söylenebilir mi? Faydasız bu fedakârlığa, neticesiz bu teșebbüse kıymet veren șey iște ahlaktır, "harabeleri güzel kılan șey”in mimari olușu gibi (A.Perret)” (Aliya, 2008: 170.) Kaldı ki, tarihöncesi İlyada ve Gılgamıs, destanlarından bu yana biz insanların mağlup kahramanlara karșı duyduğumuz hayranlığın kökeni nedir? Bu anlamda düșük bütçeli western filmleri dahi, mağdura/kaybedene karșı duyduğumuz fitri sempatiden ve maddi çıkarlara karșı duruşumuzdan faydalanmıyorlar mı? Aliya’ya göre burada mağdura duyulan sempatinin yeri zihin (akıl) değil ruhtur, yani "bu âlem"e ait olmayan prensiptir: "Anlama değil sempati diyorum, çünkü bu anlama değildir, o olamaz (Aliya, 2015: 257).

Aliya, meșru ve haklı yolda yapılan fedakârlığın akli izahının olamayacağını özellikle belirtir. Buna göre hak ve adalet uğruna yapılan fedakârlıkların hiçbir bilim ve felsefe tarafından izahı yapılamaz (Aliya, 2015: 258). Nitekim, Aliya'ya göre yararcılık ahlakı, akli argümanlarla desteklenebilir, ancak fedakârlık ahlakını, yani hakiki ahlakı akli bir temelde izah etmek imkânsızdır (Aliya, 2008: 199). Aliya, yararcılık ahlakının ahlaki davranıșta bir 'karșılık' aramasının bu ahlakın hakiki ahlak olmadığının bir ișareti olarak görmektedir. Buna göre özellikle dini ahlak kötülüğe karșı koyma ilkesini vaz ederken; yararcılık ahlakı, "ahlakın buyruklarına kimsenin uymadığı bir zamanda buna uyacak herhangi bir kimse akla ters hareket etmiș olur.” düsturundan yola çıkmaktadır. İște bu yaklașım, ahlaki davranıșta karșılık aramak anlamına gelmektedir ki bu da ahlakın șartsız olarak bağlayıcı olma prensibinden uzaklașması demektir. Dolayısıyla ahlaka nispi bir değer vermektir (Aliya, 2008: 204).

Esasında Aliya'ya göre ahlakı inkâr etmenin bir çeșidi de rasyonel inkârdır. Aristoteles'ten Russel'a kadar bütün ahlak tarihi boyunca temsilciler bulmuș olan bu akıma göre insan hayatının iki büyük muharriki zevk ve acıdır. Öyle ki bu akıma göre vicdan azabı bile ahlaki bir dünyaya ișaret etmez, olsa olsa "hareketlerimizin, muhitimizin kin ve nefretini üzerimize çekebileceğini düșünerek hissettiğimiz korkudur.” (Holbach, Systeme de la Nature) (Aliya, 2008: I96-197).

Kant'ın aklın saf ve pratik hali șeklinde bir kategorizasyona gitmek zorunda kaldığını hatırlatan (Aliya, 2008: ı88). Aliya, Kant'ın da ahlakı, 
rasyonaliteye bağlayarak tutarlı bir metafizik inșa edemediğini düșünmektedir. Nihayetinde Aliya, modern felsefenin ve onun günümüzdeki kesiti olarak çağdaș felsefenin ahlak gibi felsefenin pratik alanına yönelik tartıșmalarında tutarsızlıkla sonuçlanan bir metodolojik hata ile malul olduğunu düşünmektedir. Nitekim çağımızın önemli filozoflarından biri olarak kabul edilen Alain Badiou da günümüzün en önemli felsefi eğilimi olan etiğin mahiyetine bakıldığında onun saf bir nihilizmle, düşüncenin kendisini inkar etme tehdidiyle aynı kapıya çıktı̆̆ına işaret etmektedir. (Badiou, 20I3: s. I8) Badiou'ya göre genel olarak etik diye bir șey yoktur. Son kertede bir durumun imkânlarını sorguladığımız süreçlerin etiği vardir. (Badiou, 2OI3: s. 32)

Bilimsel bir yöntemin elverișli bir enstrüman olmadığı ahlak araștırmalarında hangi zeminden yola çıkmak gerekmektedir? Esasında teorik olarak da pratik olarak da ahlakın aklın ürünü olmadığını belirten Aliya, ahlakın rasyonel bir çözümlenmesine ilișkin bir imkâna kapı aralamazken alternatif bir argumantasyondan söz etmektedir. Bir anlamda burada ayrı bir yöntem arayıșı dile getirilmektedir.

Nitekim Aristoteles, dianoetik erdemlerden söz ederken bunların farklı türlerinden örnekler vermektedir. Öyle ki sanat (tekhne), episteme, phronesis, sophia, ve nous șeklinde geniș bir yelpazede aklın etkinliğinden söz etmektedir. Bașlica entelektüel erdemler (ya da düșünme yetisinin. erdemleri) olarak sanat (tekhne), "bilimsel" bilgi (episteme), pratik bilgelik (phronesis), felsefi bilgelik (sophia) ve sezgici akıl (nous) anılırken; moral erdemlere (karakter erdemlerine) örnek olarak da serbestlik ve 1lımlılık verilmektedir (Aristoteles, 20I4: 29, 30, 31; Tepe, I998: I8). Nihayetinde tek bir yöntemle sınırlandırılamayan felsefi düșünce bir bașka açıdan rasyonel olanın ötesine geçme çabalarını da kapsamaktadır (Bochenski, 20I6: 30)

Kitle insanının, derin düșünceden (meditation) yoksun olduğu için hiçbir yerde sır, muamma görmediğini, hazır kalıplarla idare edip hayret etmediğini, bilinmeyene ilișkin bir korku duymadığını belirten (Aliya, 2008: 70) Aliya, halbuki derin tefekkürün sır ve muammanın söz konusu olduğu yerde gerçekleșebileceğini belirterek bu çerçevede, Platon'un "felsefenin kaynağı hayrettir" ve Jaspers'in "hayret etmek öğrenmeye yönelmek demektir” sözlerini aktarır. Aliya, sırrın varlı̆̆ını görmezlikten gel- 
menin pratik ateizmin bariz özelliklerinden olduğunu vurgular (Aliya, 2008: 70). Aliya, Poetics of the Ritual of Scrifice, Talking of Notbing, Talking and the Ritual Act adlı eserlerin yazarı olan șair Miodrag Pavloviç'ten șu alıntıyı yapar: "İnsan tabiatını incelemek, kozmosun derinliklerinde kaybolmus, bir yıldızı incelemekten daha zordur..." (Aliya, 2015: 262-263).

Bu çerçevede bir muammanın keşfinden söz etmekte olan Aliya, modern araștırmacının araștırmalarında, hakikate ulașmanın birinci șartı olan muammayı reddetmesinden dolayı kendini hakikate kapattığına işaret eder. Hâlbuki Aliya'ya göre genel görelilik teorisinin ortaya çıkıșını, bașkaları için her șeyin açık olduğu bir alanda Einstein'in muamma görmüş, olmasına borçluyuz (Aliya, 2008: 70).

Aliya, söz konusu bilincin uyanmasının bilgiyle gerçekleșmeyeceğini; tam aksine bilgisizliği idrak ile şuur seviyesine çıkılabileceğine ișaret eder. Nitekim Aliya, cahil ile bilge arasındaki farkın farkında olunmayan bilgisizlik ile bilgisizliğin idrak edilmesinde ortaya çıkacağını belirtir. Bilgi ve bilgisizlik konusundaki bu izahlar, tam da Sokrates'in "bildiğim bir tek șey var ise o da hiçbir șey bilmediğimdir” sözüyle anlatılmak istenene ișaret eder.

Nihayetinde ahlaka dair bir sorușturmayı bilimsel bir araștırmanın konusu olarak görmeyen metodolojik bir tutum, elbette onu felsefi bir sorușturmanın konusu haline getirmeye devam edecek ve böylelikle insan zihninin temel sorușturma alanlarından biri olan ahlakla ilgili farklı yöntemler teklif edecektir. Burada ilginç olan husus șudur ki, etiğin irrasyonel bir kategoride konumlandırılıyor olușu ancak rasyonel bir argumantasyonla ortaya konulmaktadır ki bu durum felsefi düșüncenin ilginç ve özgün bir düșünce etkinliği olușunu gözler önüne sermektedir. Esasında Aliya ahlakın rasyonel veya bilimsel olarak sorgulanamayacağını ifade ederken alternatif bir rasyonaliteden söz etmektedir. Yani ahlakın rasyonel sorușturulmasının imkânsızlığına dair rasyonel argümanlar geliștirmektedir. Bu da bir çeșit deva ile zehri aynı imkanda bir araya getiren pharmakon durumu olsa gerektir.

\section{Sonuç}

İnsanî tecrübenin fiziki bir evren ile metafizik bir evrenin farklı boyutlarını aynı anda kușattığını esas alan Aliya, felsefedeki metafizik yiti- 
minin insan düșüncesini ciddi bir krizle karșı karșıya bıraktı̆̆ını düșünmekte ve bu krizin faturasının en çok ahlaki alanın konușulmasında kendisini belirgin kıldığını düșünmektedir. Zira Aliya, ahlaki alan gibi bilimsel kategori çerçevesine sı̆̆dırılamayacak bir problem alanında, metafizik bir çerçeveyi esas almayan çözümlemelerin tutarlı bir konuşmayı sürdüremeyeceklerini düşünmektedir. İlk gençlik yıllarından itibaren Batı felsefesinin klasik ve modern temel metinlerine nüfuz etmiș olan Aliya, eserlerinde varoluşçuluk ve mantıkçı pozitivizm gibi çağdaş felsefe akımlarının argümanlarını da ciddi bir șekilde analiz etmektedir. Batı felsefesine dair geniș bir müktesebata yasalanan Aliya, modernliğin insanın doğayla ilișkisinde de gerçekleștirmiş, olduğu dönüșümün benzerini ahlak alanında gerçekleștiremediğini vurgulamaktadır. Bu anlamda Aliya, günümüzde metaetiğin yaslandığı algoritmanın ahlak alanına ilișkin tutarlı sonuçlar üretemeyeceğini düșünmektedir.

Felsefenin olgular dünyasının disiplini olarak bilimle özdeșleștirilmesine itirazlar yöneltmekte olan Aliya, böylelikle ahlaki bir çözümleme için bilimin araștırma yöntemlerinin dıșında bașka bir yöntemin esas alınmasını teklif etmektedir. Bu çerçevede o, felsefenin yek bir yöntemi esas almadığını gündeme getirerek onun otonomisinin de korunmuș olacağını ima etmektedir. Zira Aliya'nın ișaret ettiği insana dair muamma, felsefenin esas ilgi alanıdır ve bu konuda felsefe, bilimle her zaman aynı perspektifi paylașmayabilir. Nitekim bilim felsefesi felsefi sorgulamanın bir alanını teșkil ettiği gibi sanat felsefesi de bașka bir felsefi etkinlik alanını olușturmaktadır. Bu anlamda felsefi bakıș açısını örneğin sanatla da bir araya getirmek pek ala mümkün gözükmektedir.

Nihayetinde tabiatı incelediği alıșkanlıkla ahlaka yönelen bir rasyonaliteye yaslanan bir felsefe sisteminin ahlak gibi felsefenin pratik alanına yönelik tartıșmalarında tutarsızlıkla sonuçlanan bir metodolojik hata ile malul olduğuna dikkat çeken Aliya, esasında insanın eșyaya indirgenmesine itiraz etmektedir. Bu çerçevede insanın uygarlık içerisinde makinenin bir dișlisi olarak yitimine veya yabancılașmasına dikkat çekmektedir. Aliya, esasında metafizik alandaki göçükten kaynaklanan felsefenin krizinin derinleștiğini en çok ahlaka ilișkin sorușturmalarda gözlemlenebileceğini düșünmektedir. 


\section{Kaynaklar}

Akarsu, B. (1999). Immanuel Kant'in Ablak Felsefesi. İstanbul: İnkılâp Kitabevi.

Aristoteles (2OI4). Nikomakhos 'a Etik. (Çev. S. Babür). Ankara: BilgeSu Yayıncılık.

Badiou, A. (2013). Etik, Kötülük Kavrayıșı Üzerine Bir Deneme. (Çev. T. Birkan). İstanbul: Metis Yayınları.

Bochenski, J. M. (2016). Felsefece Düşünmenin Yolları. (Çev. K. Dinçer). Ankara: Pharmakon Yayınları.

Cevizci, A. (2005). İrasyonalizm. Paradigma Felsefe Sözlügü. İstanbul: Paradigma Yayıncilı.

Delius, H. (200I). Etik. Günümüzde Felsefe Disiplinleri. (Der. \& çev. D. Özlem). İstanbul: İnkılap Kitabevi.

Descartes, R. (1997). Felsefenin İlkeleri. (Çev. M. Karasan). İstanbul: Milli Eğitim Bakanlığı Yayınları.

Heinemann, F. (200I). Etik. Günümüzde Felsefe Disiplinleri. (Der. \& çev. D. Özlem). İstanbul: İnk1lap Kitabevi.

İzzetbegoviç, A. (2008). Doğu ve Batı Arasında İslam. (Çev. S. Șaban). İstanbul: Nehir Yayınları.

İzzetbegoviç, A. (20II). Konuşmalar. (Çev. F. Altun \& R. Ahmetoğlu). İstanbul: Klasik Yayınları.

İzzetbegoviç, A. (2015). Tarihe Tanıklı̆ım. (Çev. A. Erkilet \& A. Demirhan \& H. Öz). İstanbul: Klasik Yayınlar1.

İzzetbeoviç, A. (2015). Özgürlüğe Kaçıšım, Zindandan Notlar. (Çev. H. T. Başoğlu). İstanbul: Klasik Yayınları.

Ovacık, Z. \& Evren M. (2015). Bebeklerde Ahlaki Bilinç Mümkün mü? Geçmişten Geleceğe Ablâk. (Ed. A. Ünal). Bartın: Bartın Üniversitesi Yayınları.

Ovacık, Z. (2015). Tabiat ve Șuurdan Daha Öte Bir Varlık Olarak İnsan: Aliya İzzetbegoviç'te Felsefi Antropoloji. Felsefe Dünyası, 6I, I86-2I7.

Tepe, H. (1998). Bir Felsefe Dalı Olarak Etik: "Etik” Kavramı, Tarihçesi ve Günümüzde Etik. Doğu Batı, 4, II-28.

Türer, C. (20I7). Ablâktan Felsefeye Felsefeden Ablâka. İstanbul: Dergâh Yayınları. 
Öz: Bu çalıșma, Aliya İzzetbegoviç örneğinden hareketle ahlak üzerine konușmayı mümkün kılacak meșru enstrümanların neler olduğunu tartıșmaktadır. Felsefi bir sorușturmanın akılla meșruiyet kazanacağı varsayıldığında felsefenin temel tartışma alanlarından biri olan ahlaki alanın da rasyonel bir șekilde tartışılması gerekmektedir. Peki, doğada cari olan nesnel bir yapının çözümlenmesinde kullandığımız bir yöntemi, olması gerekenlerin alanı olan ahlaki alanda da kullanabilir miyiz? Aliya'ya göre özellikle modern felsefe ahlak gibi felsefenin pratik alanına yönelik tartışmalarında tutarsızlıkla sonuçlanan bir metodolojik hata ile maluldür. Bu çerçevede Aliya, bilimin dıșinda sanat, din ve ahlak gibi kategorilere insani tecrübenin özel alanları olarak vurgu yapmakta ve ahlaki bir konușmanın farklı enstrümanlara ihtiyaç duyduğunun altını çizmektedir.

Anahtar Kelimeler: Aliya İzzetbegoviç, etik, ahlak, rasyonel ahlak, akil ve ahlak. 
A 